\title{
DISEASE SYMPTOMS AND THEIR FREQUENCY OF OCCURRENCE IN SYCAMORES (ACER PSEUDOPLATANUS L.) IN THE RYMANÓW FOREST UNIT STANDS
}

\author{
Tadeusz Kowalski, Paulina Materniak
}

\author{
Department of Forest Pathology, Agricultural University, Al. 29 Listopada 46, 31425 Kraków \\ e mail: rltkowal@cyf kr.edu.pl
}

Received: 25.10.2006

\section{S u m m a r y}

Field studies were conducted in the years 20032005 in the Rymanów Forest Unit in 13 stands aged between 40 to 100 years, which had $10 \% \quad 60 \%$ of the sycamore in their species composition. They grew on a mountain forest site (12 stands) and mountain riparian forest (1 stand). In each of them 100 trees were examined, growing next to each other in the central part of the stands. The disease symptoms, on trunks and in the crown area of each tree, and their intensity were determined according to the predefined symptomatic developmental code.

More than 80 fragments of wood and bark were collec ted from trunks of living and dead trees with local cankers and bark peeling off exposing wood. From the samples, 798 isolations were made on $2 \%$ malt agar medium.

The examined sycamores in the Rymanów Forest Unit showed a large variation in the disease symptoms and their oc currence frequency. Among 1300 analyzed trees, only $13.7 \%$ did not show external, macroscopic disease symptoms. There was a relatively large share of dead trees $(15.0 \%)$, which in indivi dual stands ranged $4.0 \quad 32.0 \%$. The most frequent symptoms in crowns were as follows: top dying (6.3\% trees), entire branch dying (16.2\%) or only their tops $(9.6 \%)$, crown thinning $(19.4 \%)$, leaf atrophy $(10.8 \%)$ and leaf discoloration $(11.6 \%)$. On syca mores trunks, the following symptoms were found: plate like and strip like necrosis of bark that was breaking, falling off and exposing wood ( $8.6 \%$ trees), local bark cankers (14.7\%), among which healed ones dominated $(10.3 \%)$, bark cracks $(14.3 \%)$ and tree cancer symptoms $(3.8 \%)$. Bark necrosis and wood exposure formed 1.5 times more frequently on the northern and western side than on the southern and eastern side, bark cracks appeared most frequently on the southern trunk side. On the cross sections of sycamore trunks, the following symptoms were found predo minantly: T shaped discolorations which appeared in the place of local healed cankers, dead wood regions in the places of local unhealed cankers and widespread bark cankers, sometimes taking the form of a sector reaching the part near the pith, and greyish

green or greenish brown wood discolorations in the form of numerous stains, especially in the trunk periphery part.

On the trunks of $184(14.2 \%)$ sycamores, perithecia of Nectria coccinea were present. They formed in the area of can kers on bark and exposed wood alike. Fruiting bodies of Nectria cinnabarina, Eutypa acharii, Melanomma pulvis-pyrius, coni diomata of Cytospora ambiens, Aposphaeria cf. pulviscula and conidiomata of Stegonsporium pyriforme occurred sporadically. From wood, the following were isolated predominantly: Basidiomycetes sp. 1, Chalara sp. 1, Cadophora fastigiata, Nectria cinnabarina and Cytospora ambiens. Chalara sp.1, with its mor phological features, best matched the anamorph of Ceratocystis coerulescens sensu lato.

Key words: Acer pseudoplatanus, disease symptoms, fungi

\section{INTRODUCTION}

Among native maple species, only sycamore (Acer pseudoplatanus L.), occurring mainly in mountain and piedmont regions in the south of Poland, is of significance in terms of forest-forming processes (Boratyński, 1999). It forms its own stands or, more frequently, occurs in a single or group form, performing the role of the improvement admixtures (Jaworski, 1994). For several years, in many such stands a relatively high frequency of occurrence of disease symptoms and dieback of sycamores has been observed, in particular in middle and older age classes. The reasons for these disturbing processes are not known yet.

Periodic intensifications of the disease processes of sycamore have already been observed in other countries, in particular Austria, Switzerland and the United Kingdom (Peace, 1962; Rawling, 1972; B evercombe and Rayner, 1978; Murray, 1978; Gregory, 1982; Jansen et al., 1992; C e ch, 1995). Attention should be paid to the great role of extreme climatic conditions in this process, in particular drought and low temperatures. The following are most often included in fungi contributing to the development of cankers on sycamore branches and trunks: Nectria cinnabarina (Tode: Fr.) Fr., Nectria coccinea (Pers.:Fr.) Fr., Dichomera 
saubinetii (Mont.) Cooke, Valsa ambiens (Pers.: Fr.) Fr., Phomopsis pustulata Died. i Diplodina acerina (Pass.) Sutton (Bevercombe i Rayner, 1978; Gregory, 1982; Grzywacz, 1999). A systemic disease of sycamores, the so-called verticiliosis, is caused by Verticillium albo-atrum Reinke et Berth. and Verticilium dahlie Kleb. (Smith, 1979). In North America and Western Europe, sycamore trunks are also affected by Cryptostroma corticale (Ell. et Ev.) Gregory et Waller (Peace, 1962; Cech, 2004). There is also a possibility of infection of sycamores by fungi causing dangerous diseases of other maple species, the diversity of which is particularly great in North America (Hepting, 1971).

The aim of the studies in the Rymanów Forest Unit was to determine disease symptoms in sycamores, the frequency of their occurrence in different-aged trees and the frequency of sycamore in the species composition, as well as to identify fungi most frequently occurring in the area of bark cankers on trunks and accompanying internal symptoms in trunk wood.

The study was conducted under a Ministry of Science and Higher Education research project No. 2 P06L 03626.

\section{MATERIAL AND METHODS}

Field studies were conducted in the years 2003 - 2005 in 13 stands of the Rymanów Forest Unit aged between 40 to 100 years, which had $10 \%-60 \%$ of sycamore in their species composition (Tab. 1). They grew on a mountain forest site, except for one stand (comp. 55b) which occurred in a mountain riparian forest. In each of them 100 trees were examined, growing next to each other in the central part of the stands, also making a measurement of their diameter at breast height. The disease symptoms, on trunks and in the crown area of each tree, and their intensity were determined according to the predefined symptomatic - developmental code.

During the field studies, more than 80 fragments were collected from trunks of living and dead trees showing symptoms of local cankers and bark peeling off exposing wood. In the laboratory, fungi were identified based on fruiting bodies present on them, a description and photo documentation of the disease symptoms were made, as well as they were prepared for the isolation of fungi. After disinfection of the samples with $96 \%$ ethanol, their more deeply situated tissues were exposed, fragments with the dimensions of about $5 \times 2$ x $2 \mathrm{~mm}$ were sampled with a sterile scalpel and placed on Petri dishes on $2 \%$ malt - agar solidified medium (Difco, Sparks, USA). In order to isolate fungi, a total of 798 wood fragments were plated on the medium. The incubation took place at a temperature of $20^{\circ} \mathrm{C}$, with no access of light. The growing fungi colonies were isolated and, along with the occurrence of spores, they were identified for species.

\section{RESULTS}

The examined sycamores in the Rymanów Forest Unit showed a large variation in the disease symptoms and their occurrence frequency. Among 1300 analysed trees, only $13.7 \%$ did not show external, macroscopic disease symptoms (Tab. 1). There was a relatively large share of dead trees $(15.0 \%)$, which in individual stands ranged $4.0-32.0 \%$ (Tab. 1). The diameter at height breast in dead trees most often ranged from 18 to $29 \mathrm{~cm}$ (Tab. 3). Top dying, found in $6.3 \%$ of trees, was a symptom occurring in tree crowns which evidenced the advanced disease process. In some stands, this symptom was proportionate to the number of dead trees, in other stands these relations were reverse (Tab. 1). Other symptoms in tree crowns included: entire branch dying or top dying, crown thinning, leaf atrophy and leaf discoloration (Tab. 1). Dead branches were present in $16.2 \%$ of trees, but in most of them less than $10 \%$ of branches in the crown had died (Fig. 1). Among trees with thinning crowns, the largest number of them had the loss of leaves ranging between $10 \%$ and $30 \%$ (Fig. 2 ). Trees with the diameter at breast height of $33-50$ $\mathrm{cm}$ showed crown thinning more than twice more often than trees with the diameter at breast height below 17 cm (Tab. 3). Leaves on thicker trees also had yellowbrown discoloration (Tab. 3). In $20.6 \%$ of the examined sycamores, symptoms of tar-spot disease were found, caused by Rhytisma acerinum (Pers.) Fr.

The disease symptoms occurring on sycamore trunks were also characterised by a large variation. The further proper growth of trees was most threatened by plate-like or strip-like necrosis of bark which then cracked and fell off, exposing wood. Such a symptom was observed in $8.6 \%$ of trees with the diameter at breast height ranging between 18 and $40 \mathrm{~cm}$ (Tab. 2, 3). Bark necrosis and wood exposure formed 1.5 times more frequently on the northern and western side than on the southern and eastern side (Fig. 3). In $14.7 \%$ of trees, local bark cankers occurred on trunks (Tab. 2), among which healed cankers were predominant $(10.3 \%)$. On trunks of $3.8 \%$ of trees, symptoms of tree cancer occurred, with different degrees of development. On trunks of $14.3 \%$ of the examined sycamores, longitudinal bark cracks occurred, sometimes exceeding even $30 \mathrm{~cm}$ in length. In $8.1 \%$ of trees, bark was cracked along the section from the rootstock up to 2 metres high, and only in $0.6 \%$ at a height of more than 4 meters. Bark cracks which did not cover more than $1 / 4$ of trunk girth were predominant $(7.2 \%)$. They were present most frequently on the southern side of trunks (Fig. 3). Frost ribs occurred only sporadically, they were found on the trunks of 5 trees (Tab. 2). Epicormic shoots also formed relatively rarely on trunks. They occurred more numerously only on 47-year-old sycamores in comp. 105a (Tab. 2). 


\begin{tabular}{|c|c|c|c|c|c|c|c|c|c|c|c|c|c|c|}
\hline \multirow{12}{*}{ 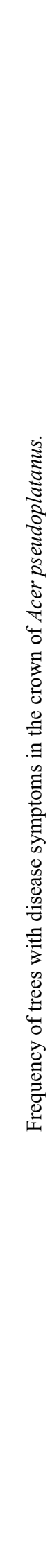 } & 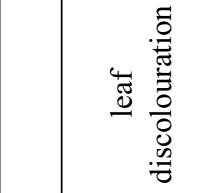 & 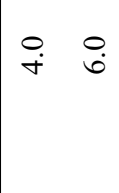 & $\stackrel{\circ}{\dot{\Xi}}$ & $\stackrel{0}{\infty}$ & $\stackrel{\circ}{r}$ & $\stackrel{\circ}{\stackrel{0}{I}}$ & 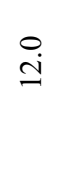 & $\stackrel{\circ}{\stackrel{0}{\leftrightarrows}}$ & $\stackrel{\ddot{g}}{\ddot{g}}$ & $\stackrel{0}{\infty}$ & $\stackrel{\circ}{=}$ & $\stackrel{\ddot{g}}{\ddot{g}}$ & $\stackrel{\circ}{\exists}$ & 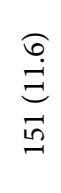 \\
\hline & 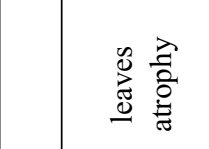 & 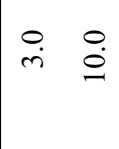 & $\stackrel{\circ}{\ddot{n}}$ & $\stackrel{\circ}{\circ}$ & $\because$ & $\because$ & $\stackrel{\circ}{=}$ & $\stackrel{\ddot{i}}{\ddot{i}}$ & $\ddot{\ddot{i}}$ & $\stackrel{\circ}{\vec{\lambda}}$ & $\ddot{0}$ & $\stackrel{\circ}{\mathrm{i}}$ & $\stackrel{\circ}{\infty}$ & $\begin{array}{l}\widehat{\infty} \\
\stackrel{0}{ٍ} \\
\stackrel{9}{9}\end{array}$ \\
\hline & 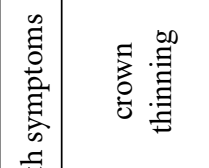 & $\stackrel{\circ}{\stackrel{0}{\leftrightarrows}}$ & $\stackrel{\circ}{i}$ & $\ddot{i}$ & $\ddot{i}$ & $\stackrel{\ddot{i}}{i}$ & $\stackrel{0}{0}$ & $\stackrel{\circ}{9}$ & $\stackrel{\ddot{v}}{\ddot{v}}$ & $\ddot{\dot{m}}$ & $\stackrel{\circ}{\circ}$ & $\stackrel{\circ}{\stackrel{.}{I}}$ & $\stackrel{0}{\infty}$ & 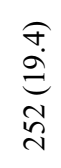 \\
\hline & 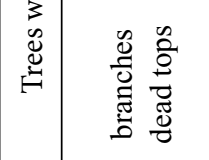 & $\stackrel{\circ}{\circ} \stackrel{\circ}{\Xi}$ & $\stackrel{0}{0}$ & $\stackrel{\circ}{\mathrm{i}}$ & $\because$ & $\because$ & $\because$ & $\stackrel{\circ}{\mathrm{I}}$ & $\stackrel{0}{\infty}$ & $\stackrel{\circ}{9}$ & $\stackrel{\circ}{\check{1}}$ & $\stackrel{0}{\infty}$ & $\stackrel{\circ}{+}$ & $\begin{array}{l}6 \\
\vdots \\
\vdots \\
\beth\end{array}$ \\
\hline & 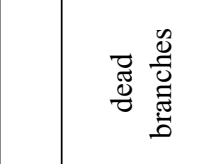 & $\stackrel{\circ}{\stackrel{\Xi}{=}} \stackrel{\circ}{I}$ & $\stackrel{\circ}{\dot{I}}$ & $\stackrel{\circ}{\dot{I}}$ & $\stackrel{\circ}{0}$ & $\stackrel{\circ}{\stackrel{0}{I}}$ & $\stackrel{\circ}{\vec{\lambda}}$ & $\stackrel{\ddot{i}}{\dot{i}}$ & $\begin{array}{l}\dot{0} \\
\infty \\
\stackrel{i}{+}\end{array}$ & $\begin{array}{l}\dot{0} \\
\infty\end{array}$ & $\stackrel{\circ}{\vec{i}}$ & $\stackrel{0}{\infty}$ & $\ddot{0}$ & 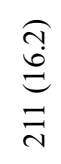 \\
\hline & 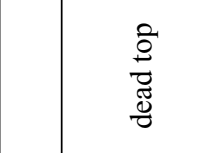 & $\begin{array}{ll}\circ & 0 \\
\dot{I} & i\end{array}$ & $\stackrel{\circ}{\mathrm{I}}$ & $\stackrel{\circ}{r}$ & $\because$ & $\ddot{i}$ & $\stackrel{\circ}{=}$ & $\stackrel{\circ}{\circ}$ & $\stackrel{0}{\dot{m}}$ & $\stackrel{\circ}{\circ}$ & $\stackrel{\circ}{-}$ & $\stackrel{\circ}{i}$ & $\stackrel{\circ}{i}$ & 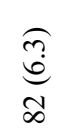 \\
\hline & 芯 & $\begin{array}{ll}\stackrel{0}{0} & \stackrel{0}{0}\end{array}$ & $\stackrel{\circ}{\dot{r}}$ & $\stackrel{0}{\infty}$ & : & $\stackrel{0}{0}$ & $\stackrel{\circ}{+}$ & ì & $\ddot{i}$ & iे & $\stackrel{\circ}{+}$ & $\stackrel{\circ}{m}$ & $\stackrel{\text { i }}{\text { r }}$ & 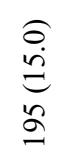 \\
\hline & 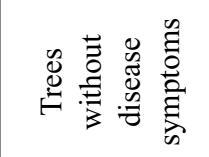 & $\begin{array}{ll}0 & 0 \\
\dot{0} & \stackrel{i}{1}\end{array}$ & $\stackrel{\circ}{i}$ & $\stackrel{\circ}{\dot{r}}$ & 官 & $\stackrel{\circ}{\vec{\lambda}}$ & $\stackrel{0}{\vec{i}}$ & $\stackrel{\circ}{\mathrm{i}}$ & in & $\stackrel{\circ}{+}$ & $\stackrel{0}{0}$ & $\stackrel{\circ}{\dot{m}}$ & $\stackrel{\circ}{a}$ & 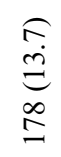 \\
\hline & 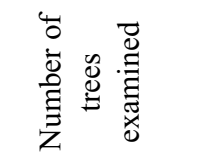 & $\nsubseteq \cong$ & 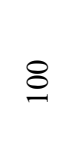 & 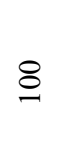 & $\cong$ & $\cong$ & 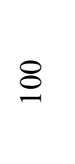 & $\nsubseteq$ & $\cong$ & $\cong$ & 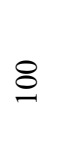 & $\cong$ & 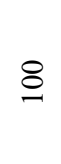 & 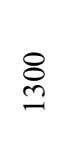 \\
\hline & 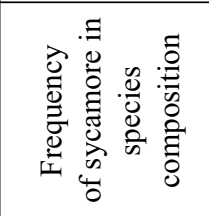 & $n n$ & in & $d$ & $\nabla$ & $n$ & - & 0 & $m$ & - & $\sim$ & $d$ & - & \\
\hline & 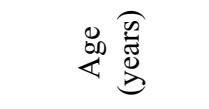 & in $\bar{n}$ & $\overline{6}$ & r & 6 & $i$ & 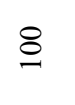 & $\vec{r}$ & F & fr & $\approx$ & \& & 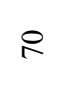 & \\
\hline & 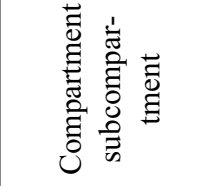 & $\begin{array}{ll}0 & 0 \\
\text { in } & \text { in }\end{array}$ & $\begin{array}{l}4 \\
\text { L }\end{array}$ & $\begin{array}{l}\infty \\
\infty \\
\infty\end{array}$ & $\bar{\infty}$ & â & 逭 & $\stackrel{\vec{\Xi}}{\Xi}$ & $\stackrel{0}{0}$ & $\stackrel{\Xi}{\text { Iิ }}$ & $\begin{array}{l}u \\
\stackrel{n}{n}\end{array}$ & $\stackrel{0}{\vec{N}}$ & $\overrightarrow{\vec{N}}$ & $\frac{\widehat{e}}{\frac{a}{0}}$ \\
\hline
\end{tabular}




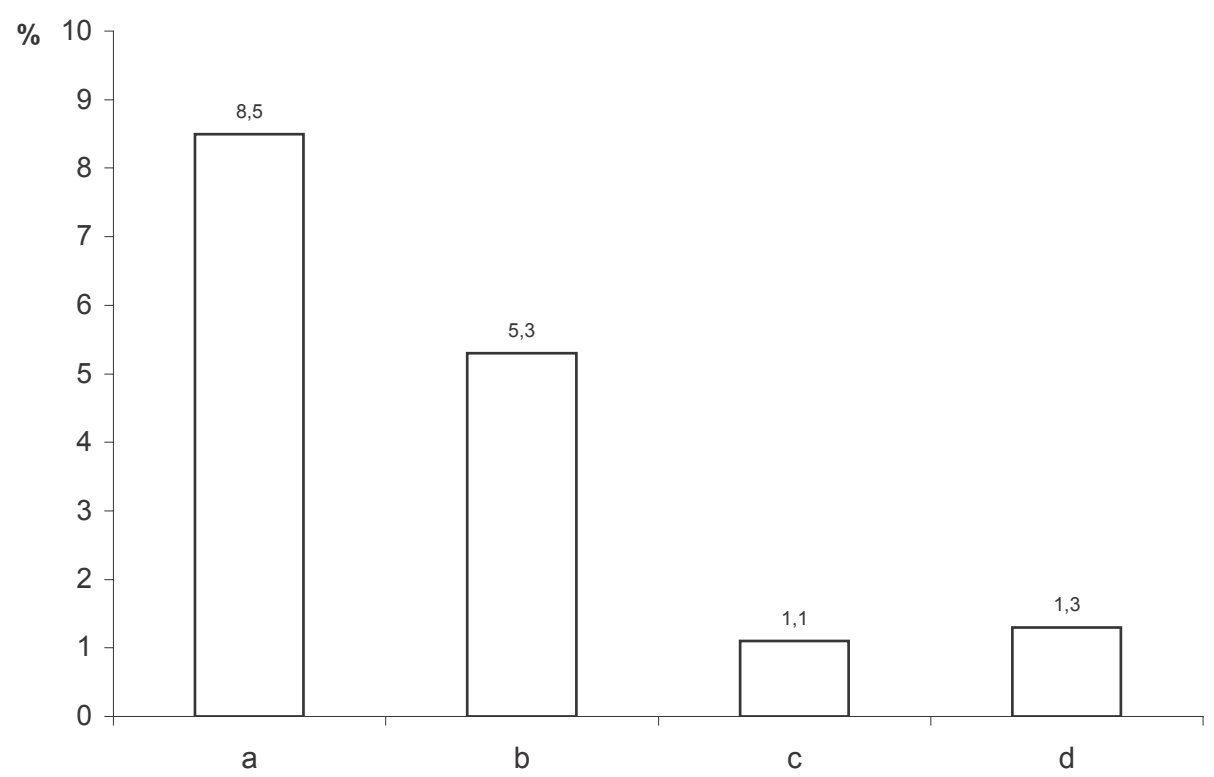

Fig. 1. Branch dying intensity in crowns of $A$. pseudoplatanus, frequency of dead branches: a to $10 \%$, b $1130 \%$, c $3150 \%$, d over $50 \%$

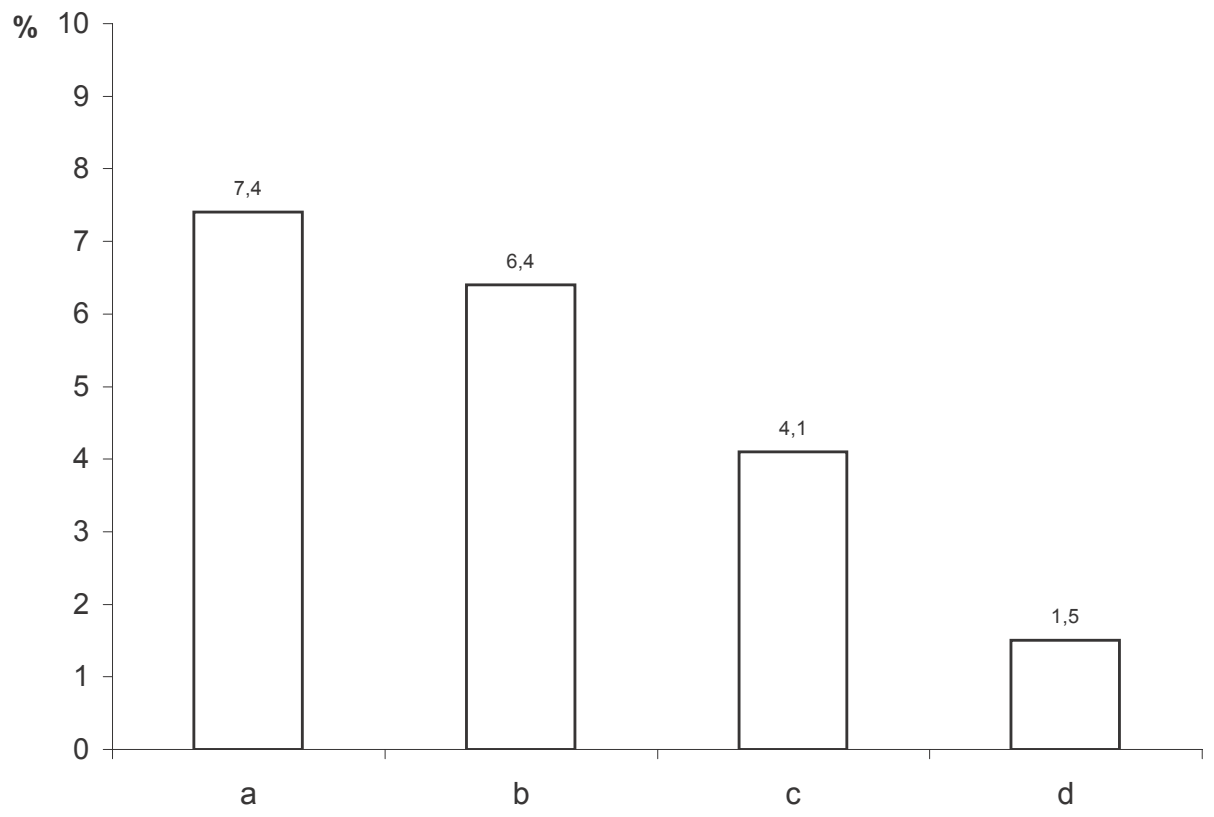

Fig. 2. Frequency of trees with crown thinning, with leaves loss: a to $10 \%$, b $1130 \%$, c $3150 \%$, d over $50 \%$. 


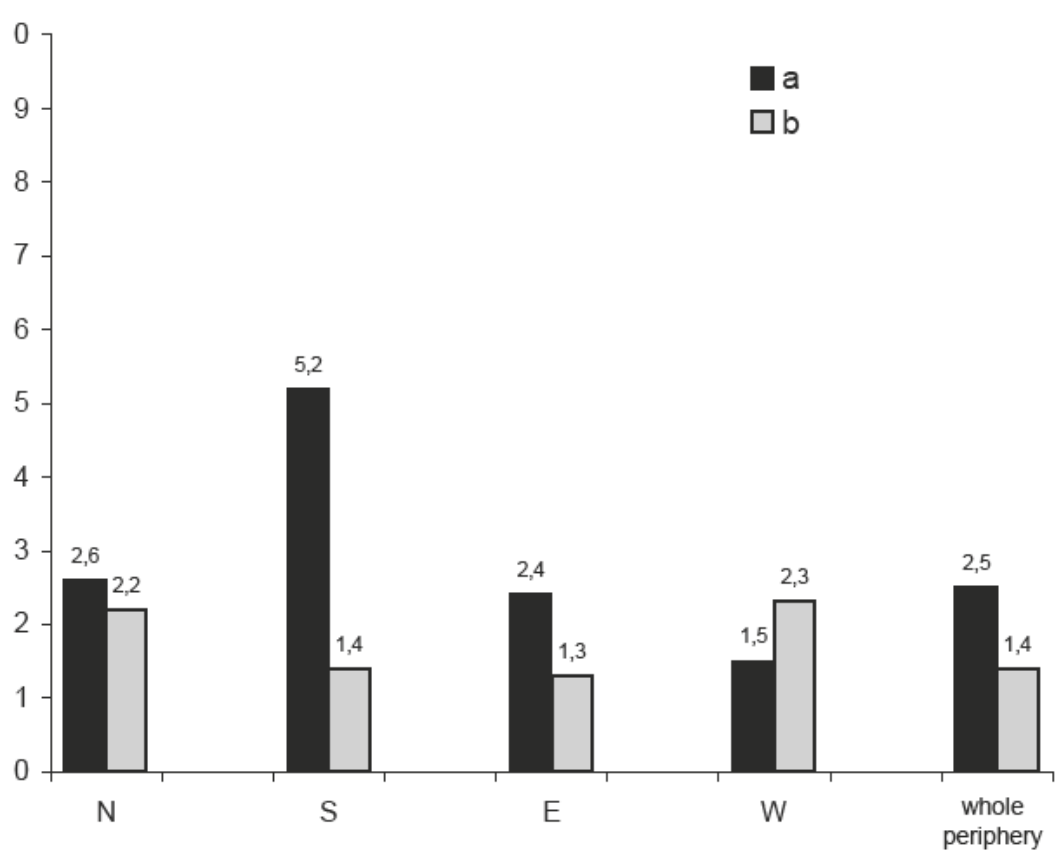

Fig. 3. Localization of bark cracks (a) and necrosis with bark falling off (b) on A. pseudoplatanus trunks according to general directions.

Table 2

Frequency of trees with damages and disease symptoms on trunks of Acer pseudoplatanus.

\begin{tabular}{|c|r|r|r|r|r|r|}
\hline \multirow{2}{*}{$\begin{array}{c}\text { Compartment } \\
\text { subcompartment }\end{array}$} & \multicolumn{7}{|c|}{ Trees with symptoms on a trunk } \\
\cline { 2 - 7 } & $\begin{array}{c}\text { necrosis with } \\
\text { bark falling off }\end{array}$ & $\begin{array}{c}\text { local } \\
\text { cankers }\end{array}$ & cancers & $\begin{array}{c}\text { bark } \\
\text { cracks }\end{array}$ & $\begin{array}{c}\text { frost } \\
\text { rib }\end{array}$ & $\begin{array}{c}\text { epicormic } \\
\text { shoots } \\
\text { on trunk }\end{array}$ \\
\hline $55 \mathrm{~b}$ & 3.0 & 19.0 & 0.0 & 9.0 & 0.0 & 0.0 \\
$56 \mathrm{a}$ & 8.0 & 25.0 & 2.0 & 5.0 & 0.0 & 0.0 \\
$56 \mathrm{f}$ & 8.0 & 14.0 & 4.0 & 7.0 & 0.0 & 0.0 \\
$58 \mathrm{a}$ & 0.0 & 28.0 & 4.0 & 22.0 & 0.0 & 0.0 \\
$58 \mathrm{j}$ & 0.0 & 10.0 & 0.0 & 20.0 & 2.0 & 0.0 \\
$59 \mathrm{~h}$ & 0.0 & 14.0 & 0.0 & 29.0 & 0.0 & 0.0 \\
$60 \mathrm{c}$ & 0.0 & 14.0 & 13.0 & 7.0 & 3.0 & 0.0 \\
$101 \mathrm{f}$ & 17.0 & 9.0 & 1.0 & 15.0 & 0.0 & 6.0 \\
$105 \mathrm{a}$ & 26.0 & 12.0 & 1.0 & 19.0 & 0.0 & 14.0 \\
$129 \mathrm{a}$ & 26.0 & 23.0 & 8.0 & 10.0 & 0.0 & 9.0 \\
$130 \mathrm{c}$ & 9.0 & 8.0 & 7.0 & 11.0 & 0.0 & 4.0 \\
$132 \mathrm{~b}$ & 6.0 & 8.0 & 8.0 & 16.0 & 0.0 & 5.0 \\
$132 \mathrm{~d}$ & 9.0 & 7.0 & 2.0 & 16.0 & 0.0 & 0.0 \\
\hline Total (\%) & $112(8.6)$ & $191(14.7)$ & $50(3.8)$ & $186(14.3)$ & $5(0.4)$ & $38(2.9)$ \\
\hline
\end{tabular}


Table 3

Disease symptoms frequency appearance on Acer pseudoplatanus according to its diameter.

\begin{tabular}{|c|c|c|c|c|c|c|}
\hline \multirow{2}{*}{ Disease symptoms type } & \multicolumn{6}{|c|}{ Frequency of trees in diameter sections $\left(\mathrm{DBH}^{*}, \mathrm{~cm}\right)$} \\
\hline & 38 & 917 & $18 \quad 29$ & 3040 & 4155 & Total $(\%)$ \\
\hline dead trees & $22(13.1)$ & $63(21.4)$ & $76(15.6)$ & $28(11.0)$ & $6(6.2)$ & $195(15.0)$ \\
\hline leaf atrophy & $0(0.0)$ & $18(6.1)$ & $74(15.2)$ & $41(16.1)$ & $7(7.2)$ & $140(10.8)$ \\
\hline leaf discolouration in crown & $4(2.4)$ & $27(9.2)$ & $53(10.9)$ & $39(15.4)$ & $28(28.9)$ & $151(11.6)$ \\
\hline crown thinning & $22(13.1)$ & $37(12.5)$ & $85(17.5)$ & $78(30.7)$ & $30(30.9)$ & $252(19.4)$ \\
\hline dead branches in a crown & $10(6.0)$ & $21(7.1)$ & $85(17.5)$ & $56(22.0)$ & $39(40.2)$ & $211(16.2)$ \\
\hline bark cracks on a trunk & $3(1.8)$ & $23(7.8)$ & $94(19.3)$ & $57(22.4)$ & $9(9.3)$ & $186(14.3)$ \\
\hline $\begin{array}{l}\text { necrosis and bark falling off } \\
\text { on a trunk }\end{array}$ & $2(1.2)$ & $11(3.7)$ & $66(13.6)$ & $28(11.0)$ & $5(5.2)$ & $112(8.6)$ \\
\hline $\begin{array}{l}\text { Number }(\%) \text { of trees in } \\
\text { diameter sections }\end{array}$ & 168 (12.9) & $295(22.7)$ & $486(37.4)$ & $254(19.5)$ & $97(7.5)$ & $1300(100.0)$ \\
\hline
\end{tabular}

* DBH diameter at breast hight

Table 4

Fungi isolated from living A. pseudoplatanus trunks with symptoms of local cankers and bark falling off exposing wood.

\begin{tabular}{|c|c|c|c|}
\hline \multirow{3}{*}{ Fungi } & \multicolumn{2}{|c|}{ Number of inhabited wood } & \multirow{3}{*}{ Total $(\%)$} \\
\hline & $\begin{array}{c}\text { fragments in trunk } \\
\text { part }\end{array}$ & & \\
\hline & periphery & inner & \\
\hline Alternaria alternata (Fr.) Keissler & 2 & & $2(0.3)$ \\
\hline Aposphaeria cf. pulviscula (Sacc.) Sacc. & 11 & & $11(1.4)$ \\
\hline Basidiomycetes sp.1 & & 148 & $148(18.5)$ \\
\hline Basidiomycetes sp. 2 & & 6 & $6(0.8)$ \\
\hline Cadophora fastigiata Lagerb. \& Melin & & 21 & $21 \quad(2.6)$ \\
\hline Chalara sp. 1 & 29 & 28 & $57 \quad(7.1)$ \\
\hline Chalara sp. 2 & 4 & & $4(0.5)$ \\
\hline Cytospora ambiens Sacc. & & 22 & $22(2.8)$ \\
\hline Diplodina acerina (Pass.) Sutton & & 1 & $1(0.1)$ \\
\hline Eutypa acharii Tul. & 9 & & $9(1.1)$ \\
\hline Fusarium solani (Mart.) Sacc. & 12 & & $12(1.5)$ \\
\hline Mollisia sp. & & 47 & $47 \quad(5.9)$ \\
\hline Nectria cinnabarina (Tode: Fr.) Fr. & 28 & & $28 \quad(3.5)$ \\
\hline Nectria coccinea (Pers.: Fr.) Fr. & 64 & 271 & $335(42.0)$ \\
\hline Stegonosporium pyriforme (Hoffm.: Fr.) Corda & 6 & & $6(0.8)$ \\
\hline Trichoderma harzianum Rifai & 2 & 11 & $13(1.6)$ \\
\hline Non sporulating fungi (3 species) & & 6 & $6(0.8)$ \\
\hline Number of „sterile” fragments & 32 & 6 & $38(4.8)$ \\
\hline Number of examined wood fragments & 186 & 612 & 798 \\
\hline
\end{tabular}




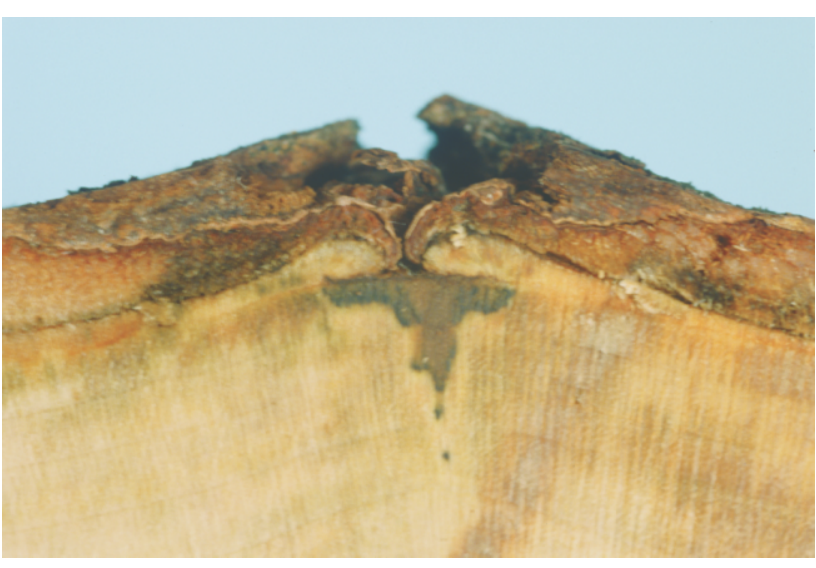

Fig. 4. Changes in sycamore wood in local healed canker place.

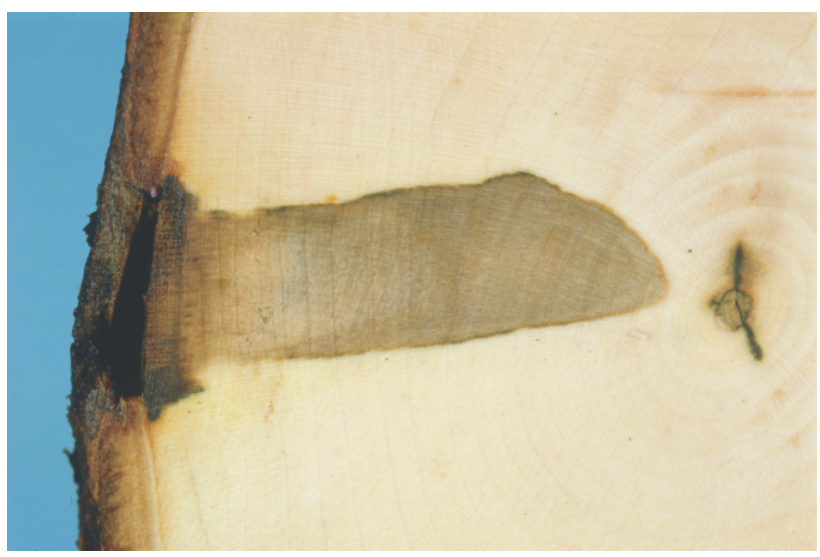

Fig. 5. Free space forming between bark and wood in place of the canker on sycamore trunk.

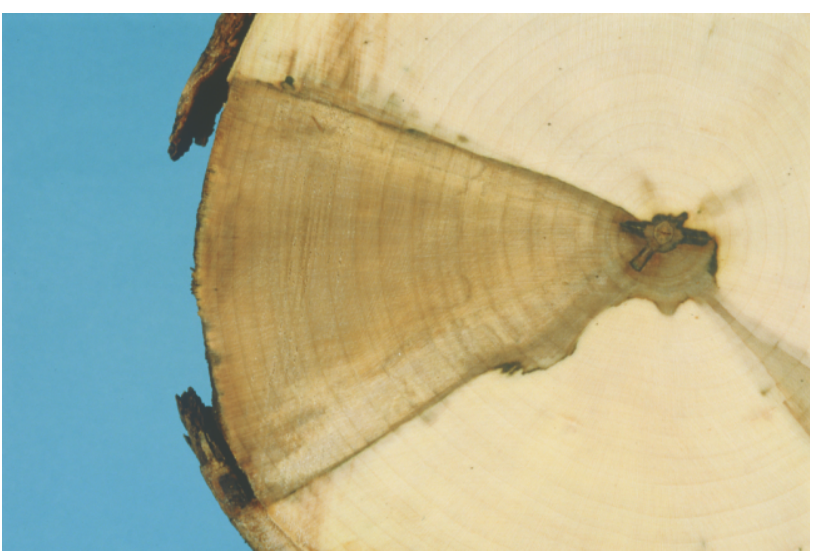

Fig. 6. Sector of dead wood as a result of stripe like bark canker on sycamore trunk.

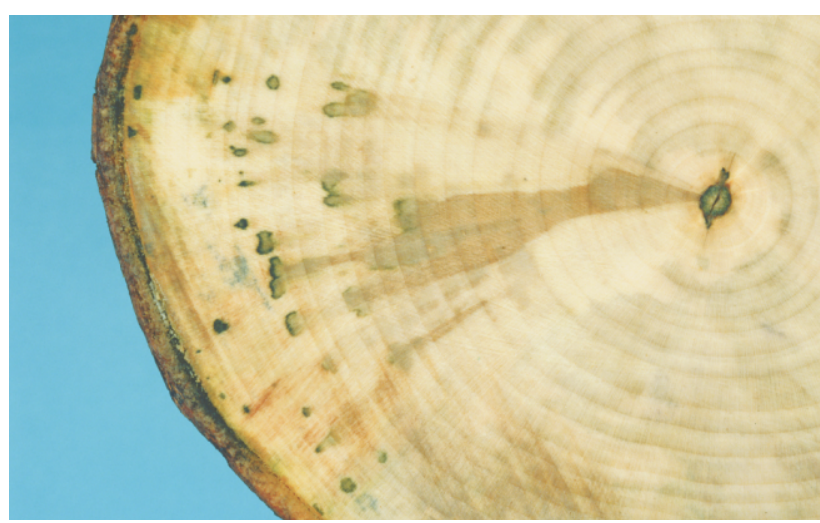

Fig. 7. Numerous local discolorations on sycamore trunk cross section.

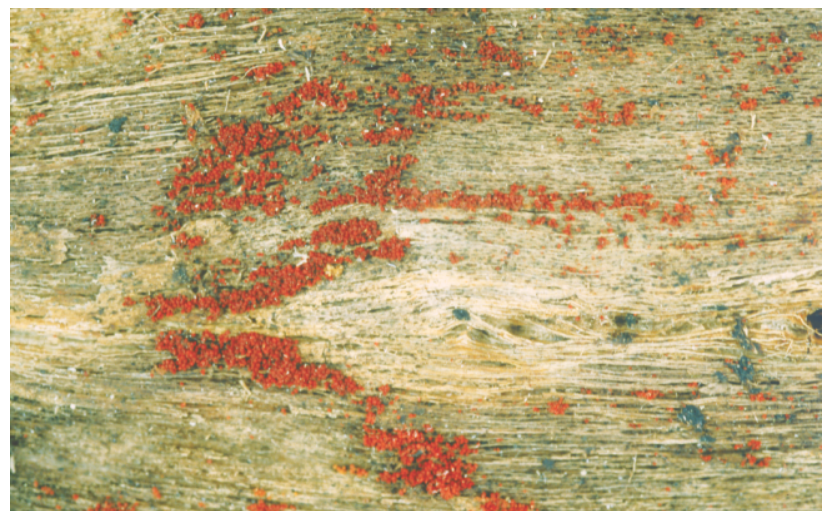

Fig. 8. Perithecia of N. coccinea on sycamore trunk in places of canker and bark falling off.

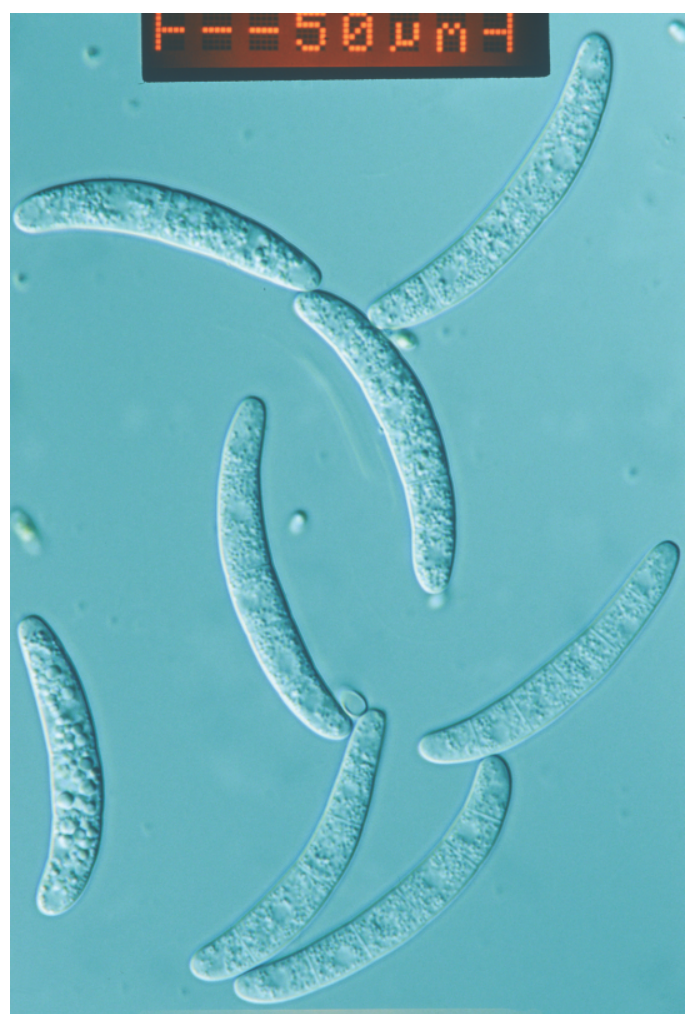

Fig. 9. Conidia of $N$. coccinea produced in culture on malt agar medium. 


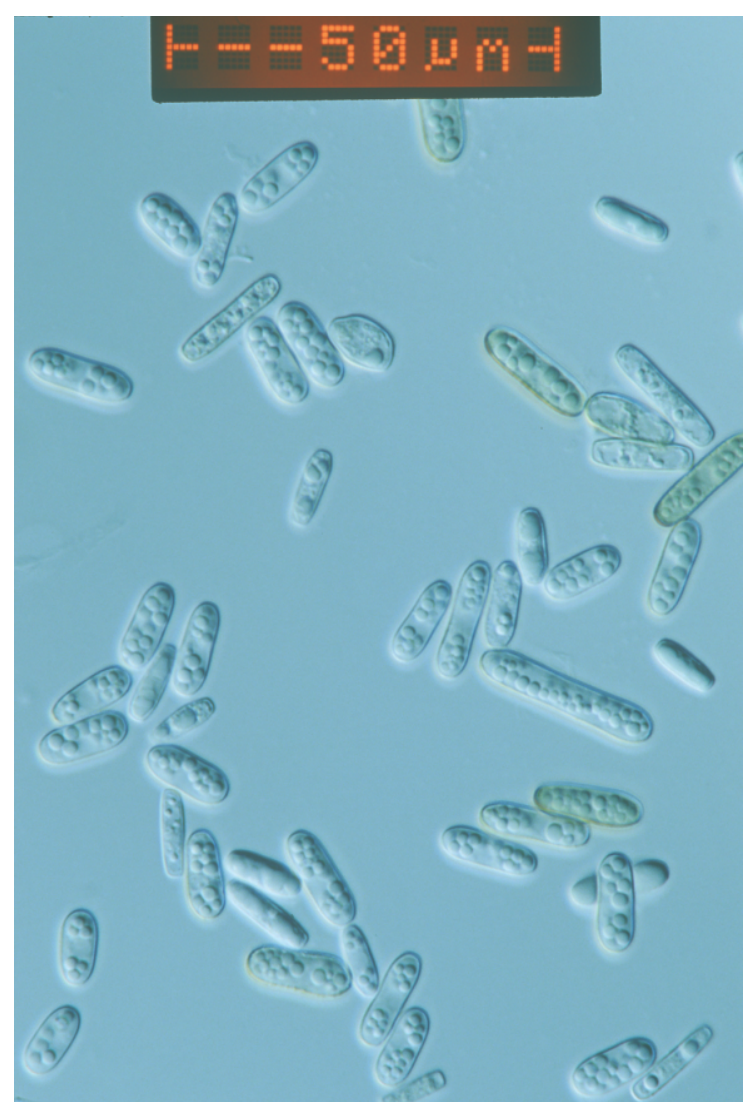

Fig. 10. Phialoconidia of Chalara sp. 1.

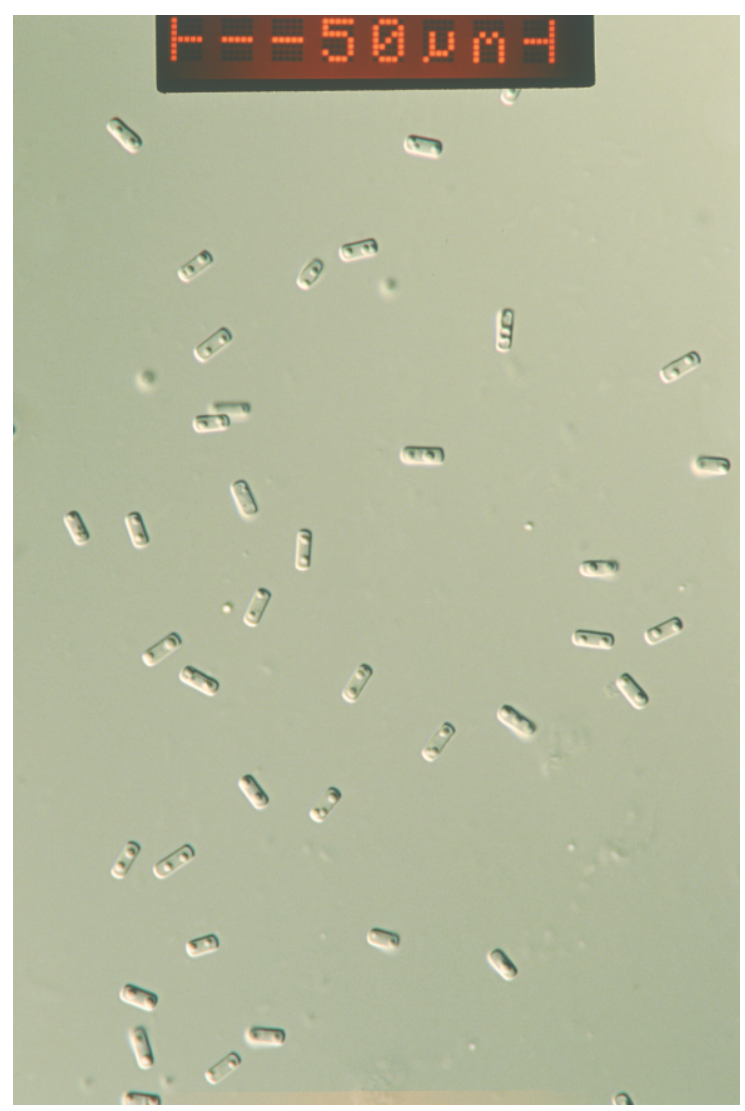

Fig. 11. Phialoconidia of Chalara sp. 2.
On the cross sections of sycamore trunks, the following internal disease symptoms occurred predominantly: T-shaped discolorations occurring in the place of local healed cankers (Fig. 4.), free spaces formed between bark and wood in the place of unhealed bark cankers (Fig. 5), dead wood regions in the place of local unhealed cankers and more widespread bark cankers, sometimes taking the form of a wedge-like sector reaching the part near the pith, in the area of which wood showed grey-brown discoloration or rot (Fig. 6), as well as grey-green or grey-brown wood discolorations in the form of spots arranged in a characteristic pattern, in particular in the part near the pith (Fig. 7).

On trunks of $184(14.2 \%)$ sycamores, perithecia of Nectria coccinea were present. They formed in the area of cankers on bark and exposed wood alike (Fig. 8). Fruiting bodies of Nectria cinnabarina, Eutypa acharii, Melanomma pulvis-pyrius and conidiomata of Cytospora ambiens, Aposphaeria cf. pulviscula and condiomata of Stegonsporium pyriforme occurred sporadically. As a result of isolations onto malt - agar medium, 19 fungi species were obtained from 798 wood fragments. The following were isolated most frequently: Nectria coccinea, Basidiomycetes sp.1, Chalara sp.1, Mollisia sp., Cadophora fastigiata, Nectria cinnabarina and Cytospora ambiens (Tab. 4). $N$. coccinea developed in vitro the anamorphic stage, known under the name of Cylindrocarpon candidum (Link) Wollenw. (Fig. 9). Species from the genus Chalara differed primarily in their size and the shape of phialoconidia (Figs. 10,11). Chalara sp.1, with its morphological features, best matched the anamorph of Ceratocystis coerulescens Muench s.l.

\section{DISCUSSION}

The analysis conducted in the stands of the Rymanów Forest Unit shows the advanced progression of the disease process in sycamores, leading relatively often to their dying. This process was observed in all the stands, irrespective of the age or the frequency of sycamore in the species composition; differences only related to its intensity. The disease symptoms found on trunks and in crowns of sycamores were characterised by a large variation, what makes them similar to the condition observed in other deciduous trees, in particular beech, oak and ash (Kowalski, 1991; Kowalski and Lukomska, 2005; Rojek, 2005). Some disease symptoms in sycamore crowns were a result of the direct infection by fungi of organs in this part of the tree. A typical example may be the symptoms of tar-spot disease of leaves caused by Rhytisma acerinum. The symptoms of leaf atrophy and discoloration, as well as 
the dieback of branches not affected by pathogenic fungi, observed in crowns, could be secondary symptoms resulting from disease-related changes on sycamore trunks, which included bark cankers of different type, shape and size. Local cankers which were healed, visible on the trunk cross section with the shape of the letter T, can be considered to be the least dangerous for the further growth of the tree. Plate-like or strip-like cankers, combined with bark cracking and falling off, should be included among the most dangerous ones. A high formation frequency of of such bark cankers type was observed in certain periods of time also in other countries. Their reasons are attributable both to abiotic and biotic factors. It has been proved in the United Kingdom that the mass occurrence of bark cankers in sycamores was related to the previous occurrence of a drought period (B evercombe and Rayner, 1978; Murray, 1978; Gregory, 1982). Bark dieback was always connected with anatomical changes in vessels and cells of the pith rays in the area of late wood of the youngest annual growth ring (Murray, 1978). However, it could not be shown whether the cambium in the regions of cankers was dying as a result of drought or infection by fungi of trees being under the stress conditions. In the area of such cankers, the presence of Nectria coccinea, Verticillium tenereum (Nees ex Pers.) Link, Diplodina acerina, Phomopsis pustulata and Dichomera saubinetii was found most frequently (Bevercombe and Rayner, 1978; Murray, 1978; Gregory, 1982). Nectria coccinea was also found numerously in the area of cankers on sycamore trunks in Upper Austria, where not climatic factors were recognised as the factor making sycamores more susceptible, but changes in the substrate associated with mining of lignite. In these sycamores, an additional symptom was several-metre-long bark cracks in the above-ground portion of trunks (C e ch, 1994). Nectria coccinea was also the species which was present most often on dead bark and in wood of trunks of the examined sycamores in the Rymanów Forest Unit. This species was similarly often found on beeches inhibited by the beech scale Cryptococcus fagisuga Lind. (Kowalski and Kleban, 2000). The ability to cause bark cankers by $N$. coccinea in sycamore and beech has been shown experimentally in the event that the inoculum was introduced in the place of injury on trunks of living trees, however, if these trees were in a good condition, cankers were of limited size and were healed (P arker, 1975; Gregory, 1982; Kow alski and Kleb a n, 2000). Fusarium solani, currently isolated from wood in the area of T-shaped healed cankers, is a fungus species found in association with such symptoms also in other species of deciduous trees (Wood and Skelly, 1964; Przybył, 1985; Kowalski, 1991). Wo od and Skelly (1964) have shown that it is able to cause, by itself, cankers of sugar maple only in the case of inoculation in the period of vegetation dormancy. Przybył (1985) has confirmed the pathogenicity of $F$. solani, inoculating four-month injured shoots of poplar. The most probable factor affecting the development of injuries on sycamore trunks, allowing the abovementioned infections and other fungus species to occur (Tab. 4), could be weather anomalies primarily related to the occurrence of low temperatures. They are particularly dangerous when they occur at the end stage of winter, and their characteristic feature is that temperature drops follow over a dozen day-long warmings, what has been shown experimentally with respect to common oak (Kow alski, 1981; Th o m a s and Hartmann, 1992).

Bark cankers and dieback of sycamores in the Rymanów Forest Unit were accompanied by characteristic internal disease symptoms, visible on trunk cross sections. The results of isolations do not show that only one fungus species is connected with a particular type of discoloration. A lot of evidence shows that the observed discolorations are an effect of an accumulation of phenolic substances in the so-called reaction regions as a result of infection of sapwood by various fungi and bacteria. In maples, they often have greenish or orange discoloration ( $\mathrm{Z}$ i m m e r m a n n, 1974; P e a r ce, 1996). Such numerous isolations of Nectria coccinea from discolored sapwood of the examined sycamores show that this species, after causing bark cankers, is able to grow across the deep layers of wood. As its mycelium may grow already at a temperature of several degrees above zero, most probably in nature the wood of sycamore trunks is infested also during the period of vegetation dormancy (Murray, 1978). In the explanation context of the of sycamore diseases causes, special attention should be paid to the establishment of the of internal symptoms presence (Fig. 7), very similar to the a disease symptoms of maples, mainly sugar maple, in North America termed "sapstreak disease of maple" (Hepting, 1971), and the isolation, from sycamores with such symptoms, of the fungus Chalara sp. 1 with its features similar to the anamorph of Ceratocystis coerulescens s.l. However, some taxonomic problems appear in this respect. In North America, Ceratocystis virescens (Davidson) Moreau is currently reported as the perpetrator of "sapstreak disease". In Europe, a morphologically similar species Ceratocystis coerulescens was treated as the perpetrator of wood blue stain of coniferous trees (B u t in, 1996). Hunt (1956) recognised these species as synonyms and they were treated in this way for several dozen years in most mycological monographs and studies (Z aj o n c and Wulf, 1997). In many studies, however, differences are indicated in the vegetation stages of these species belonging to the genus Chalara (Nag Raj and Kendrick, 1975; Kile and Walker, 1987). Ultimately, based on molec- 
ular studies, it was proved that Ceratocy stis virescens is a separate species, and within Ceratocystis coerulescens five morphological types were first distinguished (Wit thuhn et al. 1998), and then they were described as new species (Harrington and Wing field, 1998). The explanation of affiliation to species of the cultures isolated from diseased sycamores and currently identified as fungi from the genus Chalara will require further methodologically oriented taxonomic studies.

\section{REFERENCES}

Bevercombe G. P., Rayner A.D.M., 1978. Dichomera saubinetii and bark diamond canker formation in sycamore. Trans. Brit. Mycol. Soc. 71: 505507.

Boratyński A., 1999. Systematyka i geograficzne rozmieszcze nie. W: Klony / Systematics and geographic distribution. In: Maples (ed. Bugała W.) Polska Akademia Nauk, Bo gucki Wyd. Naukowe, Poznań, s. 1573.

Butin H., 1996. Krankheiten der Wald und Parkbaeume. Georg Thieme Verlag, Stuttgart.

Cech T. L., 1995. Absterben von Bergahorn (Acer pseudoplatanus L.) in Oberoesterreich. Forstschutz Aktuell, 16: 23.

Cech T.L., 2004. Bemerkenswerte Krankheiten in 2004. Forst schutz Aktuell, 32: 3134.

Gregory S. C., 1982. Bark necrosis of Acer pseudoplatanus L. in northern Britain. Eur. J. For. Path. 12: 157167.

Grzywacz A., 1999. Ważniejsze choroby infekcyjne. W: Klony / More important infection diseases. In: Maples (ed. Buga ła W.) Polska Akademia Nauk, Bogucki Wyd. Naukowe, Poznań, s. 427469.

Harrington C., Wingfield M. J., 1998. The Ceratocystis spe cies on conifers. Can. J. Bot. 76, 8: 14461457.

Hepting G. H., 1971. Diseases of forest and shade trees of the United States. USDA Forest Service, Handbook No. 386.

Hunt J., 1956. Taxonomy of the genus Ceratocystis. Lloydia, 19: 158.

Jansen E., Forster B., Engesser R., Odermatt O., Meier F., 1992. Die Forstschutzsituation in der Schweiz 1991. Allg. Forstzeitung, 7: 359.

Jaworski A., 1994. Charakterystyka hodowlana drzew leśnych / Growing characteristics of forest trees. Gutenberg, Kra ków.

Kile G.A., Walker J., 1987. Chalara australis, a vascular patho gen of Nothofagus cunninghamii in Australia and its rela tionship to other Chalara species. Australian Journ. Bot. 35: 132 .

Kowalski T., 1981. Grzyby powodujące zamieranie drzew Acer platanoides L. 'Globosum' w zadrzewieniach przyulicz nych w Tarnowie / Fungi causing the dieback of trees Acer platanoides L. 'Globosum' in street tree plantings in Tarnów. Zesz Nauk. Akad. Roln. w Krakowie Nr 164, ser. Leśnictwo, z. 13: 8392.

Kowalski T., 1991. Oak decline: I. Fungi associated with vari ous disease symptoms on overground portions of mid dleaged and old oak (Quercus robur L.). Eur. J. For. Path. 21: 136151 .

Kowalski T., Kleban J., 2000. Badania nad występowaniem i przyczynami lokalnych nekroz na pniach Fagus sylvatica L. w wybranych drzewostanach Nadleśnictwa Dukla / Studies on the occurrence and causes of local cankers on trunks of Fagus sylvatica L. in selected stands of the Dukla Forest Unit. Zesz. Naukowe AR w Krakowie nr 362, ser. Leśnictwo, 28: 2738.

Kowalski T., Łukomska A., 2005. Badania nad zamieraniem jesionu (Fraxinus excelsior L.) w drzewostanach $\mathrm{Nad}$ leśnictwa Włoszczowa / Studies on the dieback of ash (Fraxinus excelsior L.) in stands of the Włoszczowa For est Unit. Acta Agrobot. 59, 2: 429440.

Murray J. S., 1978. Death of bark in Acer pseudoplatanus asso ciated with drought. Eur. J. For. Path. 8: 6575.

Nag Raj T. R., Kendrick B., 1975. A Monograph of Chalara and Allied Genera. Wilfrid Laurier Univ. Press, Waterloo, Ontario, Canada.

Parker E. J., 1975. Some investigation with beech bark disease Nectria in southern England. Eur. J. For. Path. 5: 118124.

Peace T. R., 1962. Pathology of trees and shrubs. Clarendon Press, Oxford.

Pearce R.B., 1996. Antimicrobial defences in the wood of living trees. New Phytol. 132: 203233.

Przybył K., 1985. Mikroflora grzybowa z pni topoli z objawami brunatnej plamistości parchatej i raka typu tarczy / Fun gal microflora in poplar trunks with symptoms of brown spot and target canker diseases. Arboretum Kórnickie, 30: 269283.

Rawling K. L., 1972. Death of sycamore trees at Otley, Yorks. Quarterly J. Forestry, 66: 201207.

Rojek P., 2005. Występowanie symptomów chorobowych i wy branych czynników biotycznych związanych ze zjawi skiem zamierania buka ( Fagus sylvatica L.) w drzewo stanach Magurskiego Parku Narodowego / The occurrence of disease symptoms and selected biotic factors associ ated with the dieback of beech (Fagus sylvatica L.) in the Magurski National Park. Acta Agrobot. 59, 2: 441452.

Smith L. D., 1979. Verticillium wilt of landscape trees. Journ. Arboriculture, 5(9): 193197.

Thomas F. M., Hartmann G., 1992. Frosthaerte des Bastes aelterer Traubeneichen auf besonnten und absonnigen Stammseiten. Forst u. Holz, 47: 462464.

Witthuhn R. C., Wingfield B.D., Wingfield M.J., Wol faardt M., 1998. Monophyly of the conifer species in the Ceratocystis coerulescens complex based on DNA sequence data. Mycologia, 90(1): 96101.

Wood F. A., Skelly J. M., 1964. The etiology of an annual can ker on maple. Phytopathology, 54: 269272.

Zajonc J., Wulf A., 1997. Gefaerdet die durch Ceratocystis virescens verursachte Splintstreifenkrankheit die euro paeischen Ahornarten. Nachrichtenbl. Deut. Pflanzen schutzd., 49(12): 297300.

Zimmermann G., 1974. Untersuchungen ueber Art und Ursa chen von Verfaerbungen an Bergahorn Stammholz (Acer pseudoplatanus L.). Forstw. Cbl. 93: 247261. 


\section{Symptomy chorobowe i nasilenie ich występowania u jaworów \\ (Acer pseudoplatanus $\mathrm{L}$.) w drzewostanach Nadleśnictwa Rymanów}

Streszczenie

Badania terenowe prowadzono w latach 2003 -2005 w Nadl. Rymanów w 13 drzewostanach w wieku 40 do 100 lat, w których udział jaworu w składzie gatunkowym wynosił od 10 do $60 \%$. Rosły one na siedlisku lasu górskiego (12 drzewostanów) i na lesie łęgowym górskim (1 drzewostan). W każdym $\mathrm{z}$ nich poddano analizie 100 rosnących obok siebie drzew w środkowej części drzewostanu. Określono objawy chorobowe na pniu i w obrębie korony każdego drzewa oraz ich nasilenie według uprzednio przygotowanego kodu symptomologiczno-rozwojowego.

Pobrano ponad 80 fragmentów kory i drewna z pni martwych drzew oraz drzew żywych wykazujacych objawy lokalnych nekroz oraz złuszczania kory odsłaniającego drewno, z których wykonano 798 izolacji na $2 \%$ pożywkę agarowo-maltozową.

Badane jawory w Nadleśnictwie Rymanów wykazywały duże zróżnicowanie symptomów chorobowych i nasilenia ich występowania. Spośród poddanych analizie 1300 drzew tylko $13,7 \%$ nie wykazywało zewnętrznych makroskopowych objawów chorobowych. Stosunkowo duży był udział drzew obumarłych $(15,0 \%)$, który wynosił w poszczególnych drzewostanach od 4,0 do $32,0 \%$. Do najczęstszych symptomów w koronach drzew należały: zamieranie wierzchołka (6,3\% drzew), zamieranie całych gałęzi $(16,2 \%)$ lub ich szczytów $(9,6 \%)$, przerzedzenie korony $(19,4 \%)$, atrofia liści $(10,8 \%)$ i przebarwienie liści $(11,6 \%)$.
Na pniach jaworów stwierdzano: placowatą lub pasmową martwicę kory, która pękała, wykruszała się i odsłaniała drewno $(8,6 \%$ drzew), lokalne nekrozy kory (14,7\%), wśród których dominowały nekrozy zabliźnione $(10,3 \%)$, podłużne spękania kory $(14,3 \%)$ oraz objawy raka drzewnego $(3,8 \%)$. Do martwicy kory i odsłaniania drewna ok. 1,5 razy częściej dochodziło od strony północnej i zachodniej niż południowej i wschodniej, spękania kory występowały najczęściej od strony południowej pni.

Na przekrojach poprzecznych pni jaworów najczęściej występowały: przebarwienia w kształcie litery „T”, występujące w miejscu lokalnych zabliźnionych nekroz, obumarłe strefy drewna w miejscu lokalnych niezabliźnionych nekroz i rozległych martwic kory, przyjmujące niekiedy formę sektora sięgającego części przyrdzeniowej, i szarozielone lub zielonobrunatne przebarwienia drewna w postaci licznych plam, zwłaszcza w części przyobwodowej pnia.

Na pniach $184(14,2 \%)$ jaworów obecne były peritecja Nectria coccinea. Wykształcały się one w obrębie nekroz, zarówno na korze jak i na odsłoniętym drewnie. Sporadycznie występowały owocniki Nectria cinnabarina, Eutypa acharii, Melanoma pulvis-pyrius oraz conidiomata Cytospora ambiens, Aposphaeria cf. pulviscula i Stegonsporium pyriforme. Z drewna najliczniej izolowano: Nectria coccinea, Basidiomycetes sp.1, Chalara sp.1, Mollisia sp., Cadophora fastigiata, Nectria cinnabarina i Cytospora ambiens. Chalara sp.1 swymi cechami morfologicznymi najbardziej odpowiadała anamorfie Ceratocystis coerulescens sensu lato. 
